\title{
Effects of Feeding Prepubertal Heifers a High-Energy Diet for Three, Six, or Twelve Weeks on Mammary Growth and Composition
}

\author{
L. E. Davis Rincker, ${ }^{\star 1}{ }^{1}$ M. S. Weber Nielsen, ${ }^{*}$ L. T. Chapin, ${ }^{*}$ J. S. Liesman, ${ }^{*}$ K. M. Daniels, $†$ R. M. Akers, $\dagger$ \\ and M. J. VandeHaar*2 \\ *Department of Animal Science, Michigan State University, East Lansing 48824 \\ †Department of Dairy Science, Virginia Polytechnic Institute and State University, Blacksburg 24061
}

\begin{abstract}
The experimental objective was to determine the effects of feeding prepubertal dairy heifers a high-energy diet for 3,6 , or 12 wk on mammary growth and composition. Holstein heifers (age $=11 \mathrm{wk}$; body weight $=107$ $\pm 1 \mathrm{~kg})$ were assigned to 1 of 4 treatments $(n=16 /$ treatment). The treatment period lasted $12 \mathrm{wk}$ and treatments were H0 (low-energy diet fed for $12 \mathrm{wk}$, with no weeks on the high-energy diet); H3 (low-energy diet fed for $9 \mathrm{wk}$, followed by the high-energy diet for $3 \mathrm{wk}$ ); H6 (low-energy diet fed for $6 \mathrm{wk}$, followed by the highenergy diet for $6 \mathrm{wk}$ ); and H12 (high-energy diet for all $12 \mathrm{wk}$ ). The low- and high-energy diets were formulated to achieve 0.6 and $1.2 \mathrm{~kg}$ of average daily gain, respectively. Heifers were slaughtered at 23 wk of age and mammary tissue was collected. A longer duration of feeding the high-energy diet increased total mass of the mammary gland, extraparenchymal fat, and intraparenchymal fat, but did not alter the mass of fat-free parenchymal tissue. When adjusted for carcass weight to reflect differences in physical maturity, the mass of fatfree parenchymal tissue decreased in a linear fashion with a longer duration on the high-energy diet. Total masses of mammary parenchymal DNA and RNA were not different. However, after adjustment for carcass weight, the masses of DNA and RNA decreased as heifers were fed the high-energy diet for a longer duration. The percentages of epithelium, stroma, and lumen, the number of epithelial structures, and the developmental scores of mammary parenchymal tissue were not different among treatments. However, the percentage of proliferating epithelial cells in the terminal ductal units, as indicated by Ki-67 labeling, decreased as heifers were fed the high-energy diet for a longer duration. We concluded that feeding prepubertal heifers a high-
\end{abstract}

\footnotetext{
Received April 7, 2006.

Accepted January 20, 2008.

${ }^{1}$ Current address: Department of Agriculture, Eastern Kentucky University, Richmond 40475.

${ }^{2}$ Corresponding author: mikevh@msu.edu
}

energy diet for a longer duration resulted in a linear decrease in both the percentage of mammary epithelial cells that were proliferating and in the mass of fat-free mammary parenchyma per unit of carcass. High-energy feeding hastens puberty and, in this study, decreased mammary epithelial cell proliferation in areas of active ductal expansion. These data are consistent with the idea that feeding heifers a high-energy diet will reduce mammary parenchymal mass at puberty.

Key words: mammary growth, heifer, nutrition

\section{INTRODUCTION}

The cost of raising replacement dairy heifers accounts for approximately $20 \%$ of total dairy herd expenses (Heinrichs, 1993). Feeding a high-energy diet allows for a rapid growth rate so that heifers can be bred and calve earlier, potentially reducing costs associated with raising replacement heifers. However, mammary growth relative to body growth and milk yield are reduced when heifers that are approximately 3 to 10 mo of age are fed a high-energy diet promoting gains of greater than $1 \mathrm{~kg} / \mathrm{d}$ for periods of $12 \mathrm{wk}$ or longer (Sejrsen et al., 1982; Petitclerc et al., 1999; Radcliff et al., 2000).

Several recent studies have indicated that increasing the energy intake of calves and heifers for a short duration ( $\leq 8 \mathrm{wk}$ ) may improve mammary development and future milk yield. Increasing the energy and protein intake of calves fed milk replacer from 2 to $8 \mathrm{wk}$ of age increased body growth, mammary parenchymal mass, and content of mammary DNA and RNA (Brown et al., 2005a,b). In another study, calves were either allowed to suckle a cow or were fed milk replacer until $6 \mathrm{wk}$ of age. Calves that suckled had greater gains ( 0.86 vs. $0.56 \mathrm{~kg} / \mathrm{d}$ ) and tended to yield more milk during the first lactation (Bar-Peled et al., 1997). In a recent study, calves were either fed milk replacer, resulting in gains of $0.59 \mathrm{~kg} / \mathrm{d}$, or given free access to whole milk for two $30-\mathrm{min}$ intervals $/ \mathrm{d}$, for gains of $0.88 \mathrm{~kg} / \mathrm{d}$ (Shamay et al., 2005). Feeding whole milk to calves affected BW but not skeletal size of the adult animal and increased 
first-lactation milk yield by $4 \%$ compared with those calves fed milk replacer. Compared with a consistent moderate growth regimen, a stairstep feeding regimen for heifers, which consisted of feeding high-energy diets for $2 \mathrm{mo}$ and energy-restricted diets for $3 \mathrm{mo}$, resulted in higher concentrations of mammary DNA, RNA, and protein, and increased milk yield in dairy and beef heifers (Choi et al., 1997; Park et al., 1998). However, the mechanism(s) to explain how high-energy intake during the preweaning period or a stairstep feeding regimen for heifers increases mammary growth are unknown. One possibility is that growth of mammary tissue in preruminant calves and young heifers responds differently when these animals are fed a high-energy diet for a short duration compared with a long duration.

No published studies have directly compared the effects of feeding a high-energy diet for different durations on mammary growth. Previous studies that found a detrimental effect of feeding a high-energy diet on mammogenesis involved treatment periods of $12 \mathrm{wk}$ or greater. Thus, 12 wk was chosen as a long duration time point, 6 and 3 wk as short duration time points, and $0 \mathrm{wk}$ of feeding a high-energy diet as a baseline control treatment. The experimental objective was to determine the effects of feeding prepubertal dairy heifers a high-energy diet for a short vs. a long duration on mammary growth and composition. We hypothesized that feeding a high-energy diet for shorter durations would stimulate the growth of mammary parenchyma, but that a longer duration of feeding a high-energy diet would be detrimental to mammary growth relative to body growth in prepubertal heifers.

\section{MATERIALS AND METHODS}

\section{Animals and Dietary Treatments}

All procedures were approved by the Michigan State University Animal Care and Use Committee. Sixtyeight Holstein heifers (approximate age $=8 \mathrm{wk}$ ) were purchased from a heifer grower within 4 consecutive weeks in the fall (17 heifers/wk), with each week classified as a separate purchase group. Heifers were housed at the Michigan State University Beef Cattle Research Center and were exposed to ambient temperatures and lighting during the adaptation and treatment periods, which occurred during late fall and winter. Heifers were housed in an open-sided barn with enough space per pen $\left(50 \mathrm{~m}^{2}\right)$ to allow for exercise. Each purchase group was allowed a 3-wk adaptation period for adjustment to the facilities and diet. During this adaptation period, heifers were gradually transitioned from a diet similar to that fed before purchase to a TMR similar to a mixture of the treatment diets. One heifer within each purchase group was randomly selected and slaughtered at 11 wk of age for baseline measurements used for calculation of mammary tissue accretion rates.

At $11 \mathrm{wk}$ of age (BW $=107 \pm 1 \mathrm{~kg}), 16$ heifers within each purchase group were blocked by BW and randomly assigned within block to 1 of 4 treatments. Heifers started the study at $11 \mathrm{wk}$ of age to allow completion of the treatment period before reaching puberty. Additionally, this age was chosen because evidence already existed showing that rapid growth before 8 wk of age increases mammary parenchymal gain at a faster rate than overall body growth (Brown et al., 2005a,b). All heifers within a given treatment in the same purchase group were housed in the same pen. Thus, 4 pens of 4 heifers ( 1 pen per purchase group) were used in each of the 4 treatments. The treatment period lasted $12 \mathrm{wk}$ and treatments were as follows: H0 (low-energy diet fed for 12 wk, with no weeks on the high-energy diet); H3 (low-energy diet fed for $9 \mathrm{wk}$, followed by the highenergy diet for $3 \mathrm{wk}$ ); H6 (low-energy diet fed for $6 \mathrm{wk}$, followed by the high-energy diet for $6 \mathrm{wk}$ ); and H12 (high-energy diet for all $12 \mathrm{wk}$ ). The low-energy diet was formulated to achieve $0.6 \mathrm{~kg}$ of average daily gain and consisted of $10 \%$ straw, $33 \%$ mature alfalfa silage, $33 \%$ oatlage, and $24 \%$ concentrate on a DM basis. The low-energy diet had $0.72 \mathrm{Mcal}$ of $\mathrm{NE}_{\mathrm{G}} / \mathrm{kg}$ of $\mathrm{DM}, 16 \%$ $\mathrm{CP}$, and $45 \% \mathrm{NDF}$. The high-energy diet was formulated to achieve $1.2 \mathrm{~kg}$ of average daily gain and consisted of $20 \%$ immature alfalfa silage, $20 \%$ corn silage, and $60 \%$ concentrate on a DM basis. The high-energy diet had 1.2 Mcal of $\mathrm{NE}_{\mathrm{G}} / \mathrm{kg}$ of $\mathrm{DM}, 18 \% \mathrm{CP}$, and $23 \%$ NDF. A more detailed description of the diets is presented in the companion paper (Davis Rincker et al., 2008). Both diets and water were available ad libitum. Diets were fed as a TMR once daily between 0900 and $0930 \mathrm{~h}$.

Heifers were slaughtered at the end of the treatment period at $23 \mathrm{wk}$ of age. Heifers were allowed to consume the TMR from the prior day's feeding until they were transported at $0600 \mathrm{~h}$ via trailer to the abattoir at the Michigan State University Meats Laboratory.

\section{Tissue Collection}

Heifers were weighed, stunned by captive bolt, and killed by exsanguination. Heifers were killed on 2 different days each week for 4 consecutive weeks, with 8 heifers (2/treatment) killed per day for each purchase group. Mammary glands were quickly removed after slaughter, cleaned, and bisected through the median suspensory ligament into right and left halves. The left half was weighed, put into a plastic bag, and frozen by submersion into a dry ice and 95\% ethanol mixture. Frozen left hemiglands were stored at $-20^{\circ} \mathrm{C}$ until composition was analyzed. Mammary parenchymal tissue 
samples from the outer region furthest from the teat were excised from the right front quarter for histology. Body weights, carcass weights $(\mathbf{C W})$, rib composition, and weights of other tissues collected at slaughter are presented in the companion paper (Davis Rincker et al., 2008).

Reproductive tracts were examined to confirm that heifers were not freemartins and had not reached puberty. One heifer (treatment $=\mathrm{H} 3$ ) was a freemartin and her data were eliminated from the results. Another heifer (treatment $=\mathrm{H} 12$ ) was confirmed postpubertal after a corpus luteum was detected at slaughter and her data were removed from the study.

\section{Mammary Gland Composition}

The frozen left half of the udder was cut transversely with a band saw into 5- to $10-\mathrm{mm}$-thick slices. Slices on the anterior and posterior ends that did not contain parenchymal tissue were discarded. Slices were then placed on a cutting board and allowed to thaw slightly. Skin, teats, and lymph nodes were removed and discarded. The parenchymal tissue was dissected from the extraparenchymal fat, and these 2 types of tissue were then weighed. Parenchymal tissue was ground with liquid nitrogen into a fine powder by using a blender (Waring Commercial, New Hartford, CT). The powder was mixed and subsampled for analysis of DNA, RNA, fat, protein, and water. The DNA and RNA contents were measured as indicators of cell number and metabolic activity, respectively, by using the same methods as Tucker (1964). Fat was determined by Soxhlet ether extraction (AOAC, 1990). Crude protein was determined by using the method of Hach et al. (1987). Water was determined as the difference in weight after drying mammary parenchymal tissue in an oven at $106^{\circ} \mathrm{C}$ for $24 \mathrm{~h}$.

\section{Mammary Gland Histology}

Samples of mammary parenchymal tissue from the outer region of the right front quarter were fixed in buffered formalin for $24 \mathrm{~h}$ and then transferred to $70 \%$ ethanol until analysis. Tissue blocks were embedded in paraffin and ribbons of $5-\mu \mathrm{m}$ serial sections were then placed onto microscope slides. Sections were deparaffinized, hydrated, stained with hematoxylin and eosin, and cover slipped. Three random, but not repeating,

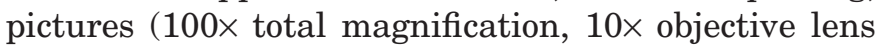
plus $10 \times$ eye-piece lens) from each microscope slide were taken for each heifer. Each of the images encompassed an area of $871,820 \mu \mathrm{m}^{2}$. The total area occupied by stroma, epithelium, and lumen was measured by using the Image-Pro Plus, Version 4.5 for Windows software program (Media Cybernetics Inc., Silver Spring, MD). This was achieved by outlining each desired structural feature; the computer program then recorded the area in square micrometers. To further characterize mammary tissue development, these same images were used for a semiquantitative evaluation of tissue development. Samples were scored (i.e., $1=$ least developed to $4=$ most developed) and the data were tabulated for analysis. The images pictured in Figure 1 illustrate the range of development noted in the tissue for these heifers and are primarily differentiated on the basis of the relative number and complexity of epithelial structures in each field. The scorer was unaware of the treatment. The number of epithelial structures per image was also tallied for each image and evaluated for each heifer. A marker for cell proliferation, Ki-67, was also visualized by staining sections with primary antibodies for Ki-67. Epithelial structures were categorized as subtending ducts (SUB) or terminal ductal units (TDU) as described and illustrated in Brown et al. (2005a). Epithelial structures were outlined by using ImagePro Plus software. The total number of Ki-67-positive epithelial cells within an outlined area was counted and divided by the total number of epithelial cells to calculate the percentage of Ki-67-positive cells, as described previously (Brown et al., 2005a). The percentage of Ki-67-positive epithelial cells was calculated for all heifers within a pen. Approximately 380 and 1,470 epithelial cells were counted for each structure within each heifer and pen, respectively.

\section{Statistical Analysis}

The PROC GLM procedure of SAS (SAS Institute, 1999) was used for statistical analysis. Pen ( $\mathrm{n}=4$ heifers per treatment in each purchase group) was used as the experimental unit, with purchase group as a random variable and treatment $\times$ purchase group as the error term. Comparisons were tested by using a linear (L) contrast with coefficients $-7,-3,1$, and 9; a quadratic $(\mathbf{Q})$ contrast with coefficients $7,-4,-8$, and 5; and a cubic $(\mathbf{C})$ contrast with coefficients $-3,8,-6$, and 1 for the $\mathrm{H} 0, \mathrm{H} 3, \mathrm{H} 6$, and $\mathrm{H} 12$ treatment groups, respectively. Least squares means and standard errors of the mean are presented. Differences were declared to be statistically significant at $P<0.05$ and tendencies at $P<0.10$. All data from the 2 heifers that were eliminated from the trial were removed so that the final animal numbers were $16,15,16$, and 15 for treatment groups $\mathrm{H} 0, \mathrm{H} 3, \mathrm{H} 6$, and $\mathrm{H} 12$, respectively.

Accretion rates for mammary and body tissues were calculated for each animal by using the average mammary and body mass of the 4 baseline heifers as initial values. These accretion rates were then calculated on 


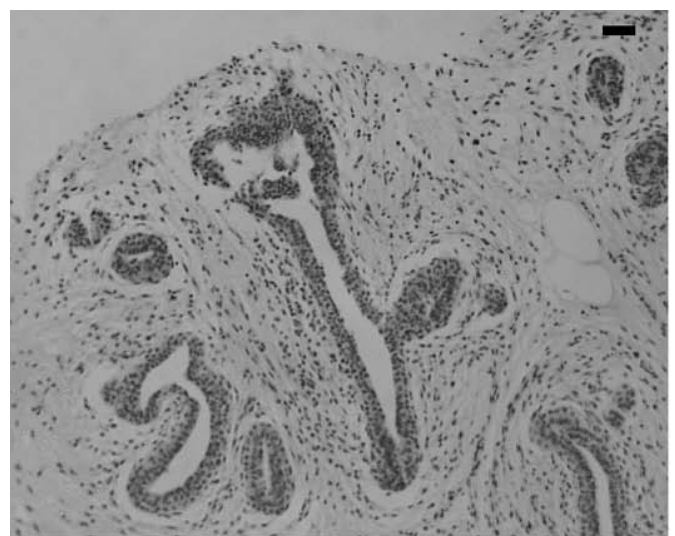

Score $=1$

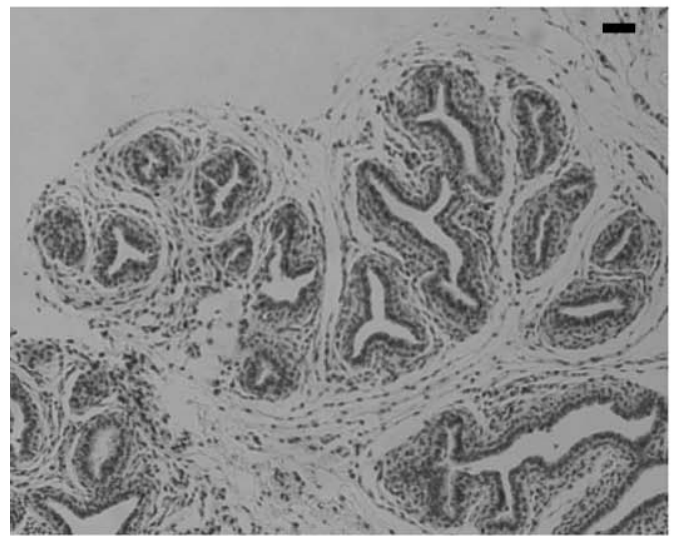

Score $=3$

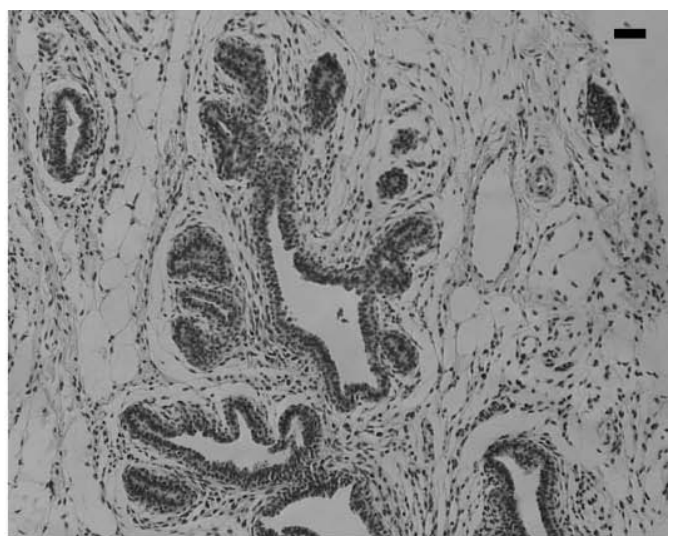

Score $=2$

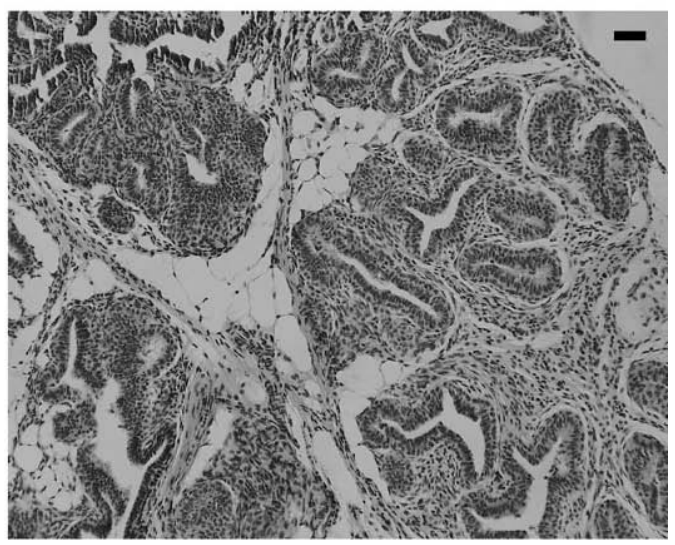

Score $=4$

Figure 1. Hematoxylin- and eosin-stained mammary parenchymal tissue from prepubertal Holstein heifers. Images represent examples that were used in scoring of the developmental score, where $1=$ least developed and $4=$ most developed. The bar indicates $50 \mu \mathrm{m}$.

a fractional basis (fractional accretion rates; FAR) that were compounded over time.

Data for extraparenchymal fat mass, intraparenchymal fat mass, intraparenchymal fat mass adjusted for $\mathrm{CW}$, fat-free parenchymal tissue mass, fat-free parenchymal tissue mass adjusted for CW, DNA mass, DNA concentration, DNA mass adjusted for CW, RNA mass, RNA mass adjusted for CW, ratio of RNA:DNA, and number of epithelial structures were log transformed to achieve homogeneous variance and normality. Percentage of lumen was transformed to the fourth root. Percentage of epithelium was normalized by raising data to a factor of 1.5. Means presented for these data points are back transformed. The error reported is the average of the back-transformed upper and lower $68 \%$ ( $\pm 1 \mathrm{SE})$ confidence intervals.

\section{RESULTS}

Actual daily gains are reported elsewhere (Davis Rincker et al., 2008) and, averaged during the treatment period, were $0.64,0.65,0.83$, and $1.09 \mathrm{~kg}( \pm 0.01)$ for the $\mathrm{H} 0, \mathrm{H} 3, \mathrm{H} 6$, and $\mathrm{H} 12$ treatment groups, respectively. During the last 2 wk of the treatment period, daily gains were $0.72,1.05,1.34$, and $1.19 \mathrm{~kg}( \pm 0.09)$ for the H0, H3, H6, and H12 groups, respectively. Body and CW are reported in Table 1.

Total mass of the mammary gland increased as heifers were fed the high-energy diet for a longer duration (Table 2; L: $P<0.01$ ). This was due to a linear increase in extraparenchymal fat (L: $P<0.01$ ), because parenchymal tissue mass was not different (all contrasts: $P$ $>0.10$ ). When adjusted for $\mathrm{CW}$ to more accurately reflect the differences in physiological maturity of the heifers, parenchymal tissue mass tended to decrease as heifers were fed the high-energy diet for a longer duration (L: $P=0.06$ ). Similar to extraparenchymal fat, intraparenchymal fat mass and also the percentage of intraparenchymal fat increased as heifers were fed the high-energy diet for a longer duration (L: $P<0.01$ ). When adjusted for CW, extraparenchymal fat increased in heifers fed the high-energy diet for a longer duration, 
Table 1. Least squares means for body and carcass characteristics

\begin{tabular}{|c|c|c|c|c|c|c|c|c|}
\hline \multirow[b]{2}{*}{ Item } & \multicolumn{4}{|c|}{ Treatment group ${ }^{1}$} & \multirow[b]{2}{*}{$\mathrm{SE}^{2}$} & \multicolumn{3}{|c|}{$P$-value for contrast ${ }^{3}$} \\
\hline & $\mathrm{HO}$ & H3 & $\mathrm{H} 6$ & H12 & & $\mathrm{L}$ & $\mathrm{Q}$ & $\mathrm{C}$ \\
\hline Heifers, $\mathrm{n}$ & 16 & 15 & 16 & 15 & & & & \\
\hline Initial BW, kg & 106 & 108 & 108 & 108 & 0.74 & 0.25 & 0.19 & 0.72 \\
\hline BW at slaughter, $\mathrm{kg}$ & 165 & 167 & 181 & 203 & 1.10 & $<0.01$ & $<0.01$ & $<0.01$ \\
\hline Carcass weight, kg & 76.6 & 82.5 & 91.5 & 107 & 0.65 & $<0.01$ & 0.40 & 0.10 \\
\hline
\end{tabular}

${ }^{1}$ Treatment groups are as follows: heifers in the H0, H3, H6, and $\mathrm{H} 12$ treatment groups were fed the lowenergy diet for $12,9,6$, or $0 \mathrm{wk}$, followed by the high-energy diet for $0,3,6$, or $12 \mathrm{wk}$, respectively. The low-energy diet and high-energy diet were formulated for gains of 0.6 and $1.2 \mathrm{~kg} / \mathrm{d}$, respectively.

${ }^{2}$ Pooled SE using treatment $\times$ purchase group or pen as the error term, with 4 pens per treatment

${ }^{3} \mathrm{~L}=$ linear; $\mathrm{Q}=$ quadratic; $\mathrm{C}=$ cubic.

but there was no effect on adjusted intraparenchymal fat (L: $P<0.01$; all contrasts: $P>0.10$, respectively). Fatfree parenchymal tissue mass relative to $\mathrm{CW}$ decreased with a longer duration on the high-energy diet (Table 2 and Figure 2; L: $P<0.01$ ). Mammary parenchymal protein mass was not different, but the percentage of protein in mammary tissue tended to be lower with a longer duration of feeding the high-energy diet and to have a cubic relationship (L: $P=0.09$ and C: $P=0.08$ ). It is not known why there was a tendency for a cubic effect on this parameter.

The total mass of parenchymal DNA and RNA and concentration of DNA were not different among treatment groups (Table 3; all contrasts: $P>0.10$ ). A linear decrease with a longer duration fed the high-energy diet was evident when DNA mass was adjusted for CW (L: $P=0.05$ ). Both the concentration of RNA and the ratio of RNA:DNA displayed a cubic effect, with the greatest abundance of mammary RNA within the H3 heifers (C: $P=0.07$ and $P=0.05$, respectively). This cubic effect was primarily because of the H3 treatment, which was high for both of these parameters.

Mammary histology data are shown in Table 4. The percentages of epithelium, stroma, and lumen within the mammary parenchymal tissue were all similar (all contrasts: $P>0.10$ ). The number of epithelial structures per field and the developmental score were also not different (all contrasts: $P>0.10$ ). The percentage of

Table 2. Least squares means for mammary gland composition ${ }^{1}$

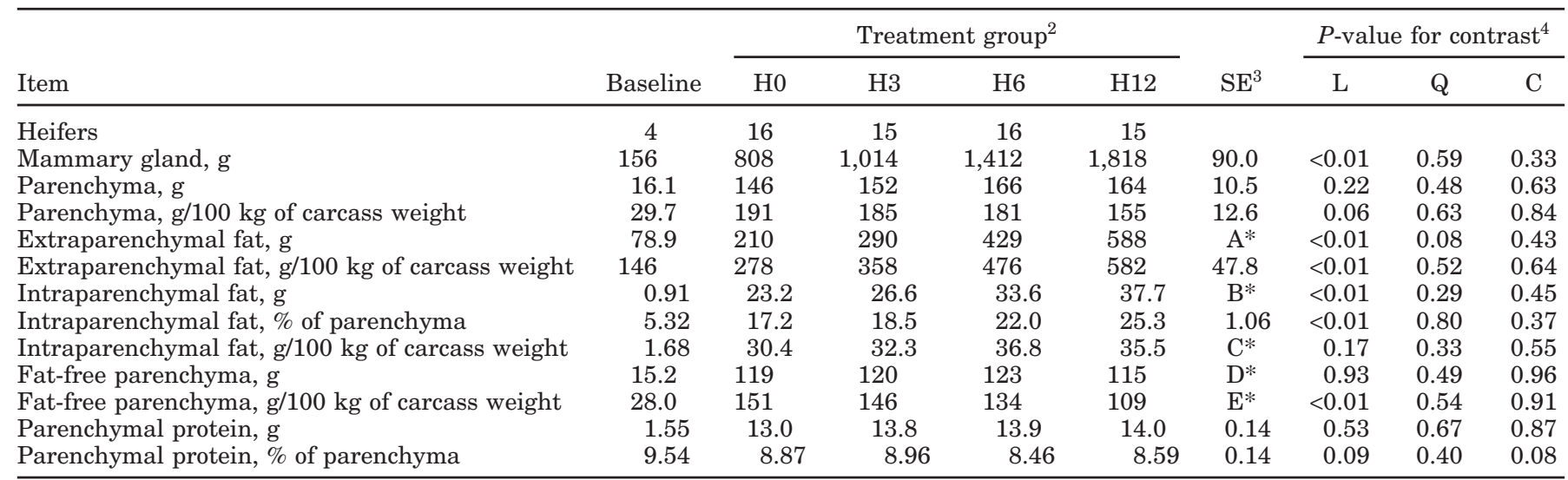

${ }^{1}$ An asterisk $(*)$ indicates that data were log transformed to achieve homogeneous variance. Means presented are back transformed. The error term indicated below is the average of the lower and upper confidence intervals for each treatment group. An "A" indicates that average confidence intervals are 15.7, 22.6, 32.0, and 45.7 for the $\mathrm{H} 0, \mathrm{H} 3, \mathrm{H} 6$, and $\mathrm{H} 12$ treatment groups, respectively. A "B" indicates that average confidence intervals are 1.79, 2.14, 2.60, and 3.03 for the $\mathrm{H} 0, \mathrm{H} 3, \mathrm{H} 6$, and $\mathrm{H} 12$ treatment groups, respectively. A "C" indicates that average confidence intervals are 2.38, 2.63, 2.88, and 2.89 for the H0, H3, H6, and H12 treatment groups, respectively. A "D" indicates that average confidence intervals are 8.58, 8.99, 8.82, and 8.62 for the H0, H3, H6, and H12 treatment groups, respectively. An "E" indicates that average confidence intervals are 10.7, 10.7, 9.47, and 7.97 for the H0, H3, H6, and $\mathrm{H} 12$ treatment groups, respectively.

${ }^{2}$ Treatment groups are as follows: heifers in the H0, H3, H6, and H12 treatment groups were fed the low-energy diet for 12, 9, 6, or 0 wk followed by the high-energy diet for $0,3,6$, or $12 \mathrm{wk}$, respectively. The low-energy diet and high-energy diet were formulated for gains of 0.6 and $1.2 \mathrm{~kg} / \mathrm{d}$, respectively.

${ }^{3}$ Pooled SE using treatment $\times$ purchase group or pen as the error term, with 4 pens per treatment.

${ }^{4} \mathrm{~L}=$ linear; $\mathrm{Q}=$ quadratic; $\mathrm{C}=$ cubic. 

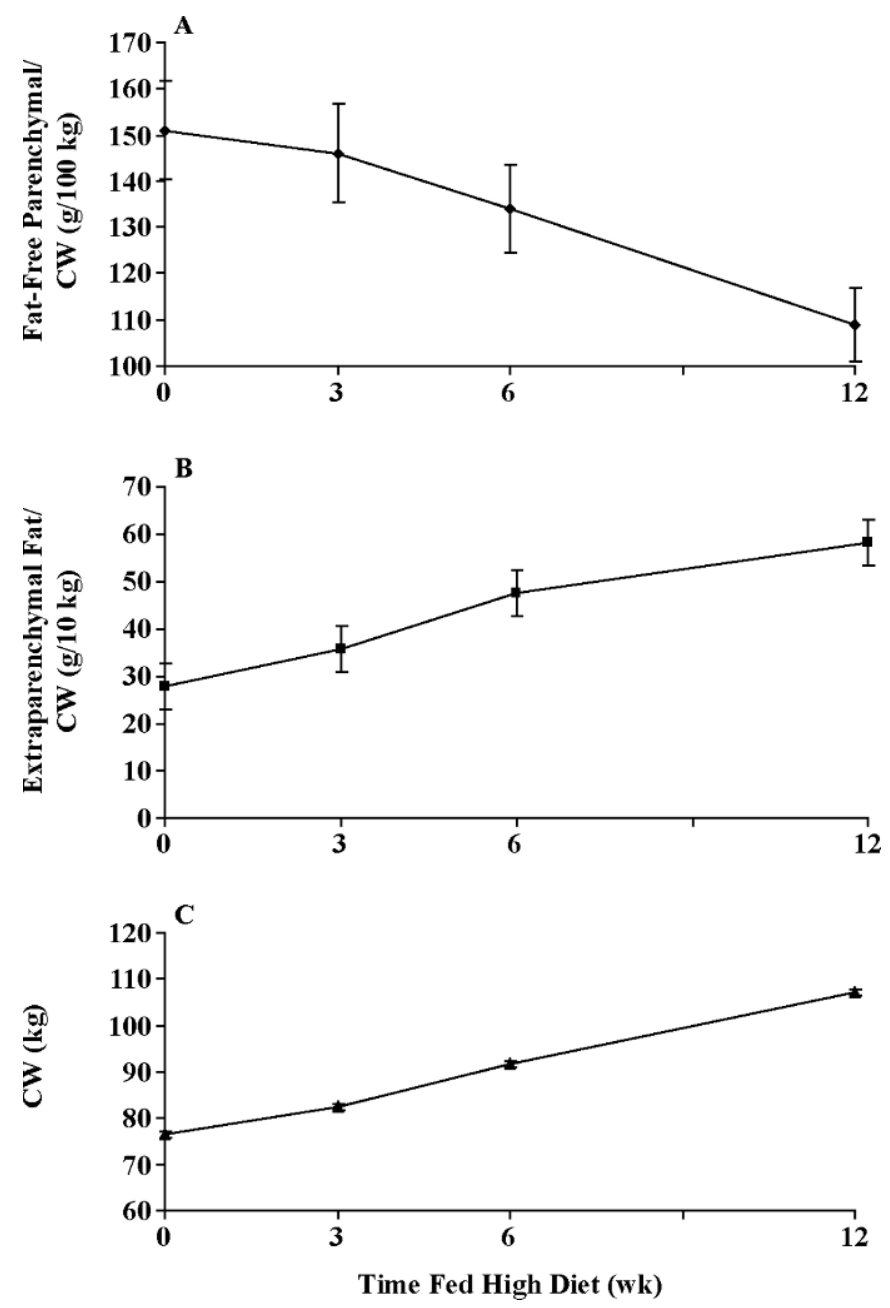

Figure 2. Grams of fat-free parenchyma relative to $100 \mathrm{~kg}$ of carcass weight (CW; A), grams of extraparenchymal fat relative to $10 \mathrm{~kg}$ of CW (B), and kilograms of CW (C). Heifers ( $=15$ or 16/ treatment) in the $\mathrm{H} 0, \mathrm{H} 3, \mathrm{H} 6$, and $\mathrm{H} 12$ treatment groups were fed the low-energy diet for $12,9,6$, or 0 wk, followed by the high-energy diet for $0,3,6$, or $12 \mathrm{wk}$, respectively. All measurements: linear: $P<0.01$. For fat-free parenchyma relative to $\mathrm{CW}$, data were log transformed to achieve homogeneous variance.

proliferating epithelial cells in the TDU, as indicated by Ki-67 labeling, decreased as heifers were fed the high-energy diet for a longer duration (L: $P=0.04$ ). The percentage of Ki-67-positive epithelial cells in the subtending ducts was not different (all contrasts: $P>$ $0.10)$.

Daily compounded FAR of extraparenchymal fat and intraparenchymal fat within the mammary gland increased as heifers were fed the high-energy diet for a longer duration (Table 5; L: $P<0.01$ ). Body weight was significant for $\mathrm{L}$ and $\mathrm{Q}$ effects (L: $P<0.01$ and $\mathrm{Q}: P=$ 0.01 for both measurements), whereas $\mathrm{CW}$ was significant only for $\mathrm{L}$ effects $(P<0.01)$. Daily accretion rates for mammary parenchyma, fat-free parenchyma, mam- mary DNA, and mammary RNA did not change with time fed the high-energy diet (all contrasts: $P>0.10$ ).

\section{DISCUSSION}

Feeding a more energy-dense diet caused no change in the amount of fat-free parenchymal mass or DNA, as recently shown by Meyer et al. (2006b). However, the heifers in our study were all killed at the same age, and BW and CW were greater for those fed the highenergy diet for a longer duration. Thus, when data were adjusted for CW, feeding prepubertal dairy heifers a high-energy diet for a longer duration resulted in a linear decrease in fat-free mammary parenchymal mass and a linear increase in mammary fat mass. These results are in agreement with other studies that have demonstrated an impairment of mammogenesis in prepubertal heifers fed high-energy diets for time periods of 12 wk or more (Sejrsen et al., 1982; Petitclerc et al., 1999). Similar to earlier work (Capuco et al., 1995; Radcliff et al., 1997), these findings indicate that highenergy intake in prepubertal heifers resulted in accelerated body growth rates, but also increased fat deposition within the mammary gland. However, this was the first study to demonstrate the effects of feeding prepubertal heifers a high-energy diet for shorter durations on mammary growth.

The original hypothesis was that a shorter duration of feeding a high-energy diet would stimulate mammary parenchymal growth relative to body growth. This idea originated from observations in compensatory growth studies and nutritional studies during the preweaning growth phase. Compensatory growth studies indicated that a stairstep feeding regimen of alternating feed intake of heifers by 25 to $30 \%$ above recommendations for a length of 2 mo and 20 to $30 \%$ below recommendations for a length of 3 to 5 mo can enhance the lactation potential of heifers (Choi et al., 1997). The mechanism for this phenomenon is not known. The positive influence on mammary growth could be due to the stairstep regimen or potentially the short time period that heifers were fed for rapid growth. However, some have suggested that the rapid growth phases of the stairstep regimen are either completely or partly outside a critical window when high-energy diets impair mammary growth (Sejrsen and Purup, 1997). During the preweaning period, increasing the energy and protein intake in calves for a period of $6 \mathrm{wk}$ ( 2 to $8 \mathrm{wk}$ of age) resulted in an increase in body growth and nearly a doubling of mammary parenchymal DNA (Brown et al., 2005a,b). However, increasing the energy and protein intake of postweaned calves from 8 to $14 \mathrm{wk}$ of age increased both body growth and mammary parenchymal growth at the same rate (Brown et al., 2005a). Other studies 
Table 3. Least squares means for mammary gland nucleic acid content ${ }^{1}$

\begin{tabular}{|c|c|c|c|c|c|c|c|c|c|}
\hline \multirow[b]{2}{*}{ Item } & \multirow[b]{2}{*}{$\mathrm{BL}$} & \multicolumn{4}{|c|}{ Treatment group ${ }^{2}$} & \multirow[b]{2}{*}{$\mathrm{SE}^{3}$} & \multicolumn{3}{|c|}{$P$-value for contrast ${ }^{4}$} \\
\hline & & $\mathrm{H} 0$ & H3 & $\mathrm{H} 6$ & H12 & & $\mathrm{L}$ & $\mathrm{Q}$ & $\mathrm{C}$ \\
\hline Heifers, $n$ & 4 & 16 & 15 & 16 & 15 & & & & \\
\hline DNA, mg/100 kg of carcass weight & 138 & 1,051 & 1,043 & 1,002 & 848 & $\mathrm{~B}^{*}$ & 0.05 & 0.48 & 0.99 \\
\hline DNA concentration, $\mathrm{mg} / \mathrm{g}$ & 4.59 & 5.75 & 5.86 & 5.82 & 5.81 & $\mathrm{C}^{*}$ & 0.90 & 0.69 & 0.72 \\
\hline Parenchymal RNA, mg & 129 & 767 & 875 & 871 & 850 & $\mathrm{D}^{*}$ & 0.49 & 0.30 & 0.63 \\
\hline RNA, mg/100 kg of carcass weight & 238 & 1,004 & 1,062 & 953 & 801 & $\mathrm{E}^{*}$ & 0.03 & 0.34 & 0.52 \\
\hline
\end{tabular}

${ }^{1}$ An asterisk $(*)$ indicates that data were log transformed to achieve homogeneous variance. Means presented are back transformed. The error term indicated below is the average of the lower and upper confidence intervals for each treatment group. An "A" indicates that average confidence intervals are 58.8, 65.6, 67.2, and 68.7 for the $\mathrm{H} 0, \mathrm{H} 3, \mathrm{H} 6$, and $\mathrm{H} 12$ treatment groups, respectively. A "B" indicates that average confidence intervals are 75.6, 78.1, 72.1, and 68.5 for the $\mathrm{H} 0, \mathrm{H} 3, \mathrm{H} 6$, and $\mathrm{H} 12$ treatment groups, respectively. A "C" indicates that average confidence intervals are $0.13,0.14,0.13$, and 0.14 for the H0, H3, H6, and H12 treatment groups, respectively. A "D" indicates that average confidence intervals are 57.6, 68.4, 65.4, and 66.5 for the H0, H3, H6, and H12 treatment groups, respectively. An "E" indicates that average confidence intervals are 73.8, 81.3, 70.1, and 61.3 for the H0, H3, H6, and H12 treatment groups, respectively. An "F" indicates that average confidence intervals are $0.02,0.03,0.02$, and 0.02 for the H0, H3, H6, and H12 treatment groups, respectively.

${ }^{2}$ Treatment groups are as follows: heifers in the H0, H3, H6, and H12 treatment groups were fed the low-energy diet for 12, 9, 6, or 0 wk, followed by the high-energy diet for $0,3,6$, or $12 \mathrm{wk}$, respectively. The low-energy diet and high-energy diet were formulated for gains of 0.6 and $1.2 \mathrm{~kg} / \mathrm{d}$, respectively.

${ }^{3}$ Pooled SE using treatment $\times$ purchase group or pen as the error term, with 4 pens per treatment.

${ }^{4} \mathrm{~L}=$ linear; $\mathrm{Q}=$ quadratic; $\mathrm{C}=$ cubic.

have measured an increase in 300-d milk production and daily FCM yield when heifers were allowed greater gains during the preweaning period (Bar-Peled et al., 1997; Shamay et al., 2005). The reason high-energy and high-protein intake might stimulate mammogenesis during the preweaning period but have no effect or even impair mammogenesis after weaning is not understood. We hypothesized that the short duration of high-energy intake preweaning might be part of the explanation. However, the results from this study using older prepu-

Table 4. Least squares means for mammary gland histology ${ }^{1}$

\begin{tabular}{|c|c|c|c|c|c|c|c|c|}
\hline \multirow[b]{2}{*}{ Item } & \multicolumn{4}{|c|}{ Treatment group ${ }^{2}$} & \multirow[b]{2}{*}{$\mathrm{SE}^{3}$} & \multicolumn{3}{|c|}{$P$-value for contrast ${ }^{4}$} \\
\hline & Ho & H3 & H6 & H12 & & $\mathrm{L}$ & $\mathrm{Q}$ & $\mathrm{C}$ \\
\hline Heifers, $\mathrm{n}$ & 16 & 15 & 16 & 15 & & & & \\
\hline Parenchymal area, \% & & & & & & & & \\
\hline Epithelium & 19.9 & 19.7 & 20.8 & 18.4 & $\mathrm{~A}^{*}$ & 0.14 & 0.12 & 0.49 \\
\hline Stroma & 73.0 & 72.9 & 72.3 & 74.7 & 2.9 & 0.30 & 0.36 & 0.72 \\
\hline Lumen & 6.77 & 5.47 & 6.50 & 6.37 & $\mathrm{~B}^{*}$ & 0.59 & 0.88 & 0.46 \\
\hline Developmental score ${ }^{5}$ & 2.39 & 2.17 & 2.26 & 2.22 & 0.16 & 0.61 & 0.62 & 0.52 \\
\hline $\begin{array}{l}\text { Epithelial structures, n } \\
\text { Ki- } 67,{ }^{6} \% \text { labeling }\end{array}$ & 15.0 & 14.0 & 12.9 & 14.1 & $\mathrm{C}^{*}$ & 0.69 & 0.38 & 0.80 \\
\hline TDU & 3.26 & 3.06 & 2.70 & 2.26 & 0.40 & 0.04 & 0.94 & 0.84 \\
\hline SUB & 2.59 & 2.95 & 1.74 & 1.82 & 0.50 & 0.16 & 0.80 & 0.19 \\
\hline
\end{tabular}

\footnotetext{
${ }^{1}$ An asterisk (*) indicates that the data were transformed to achieve homogeneous variance. Means presented are back transformed. The error term indicated below is the average of the lower and upper confidence intervals for each treatment group. An "A" indicates that average confidence intervals are 0.73 , $0.92,0.90$, and 0.73 for the $\mathrm{H} 0, \mathrm{H} 3, \mathrm{H} 6$, and $\mathrm{H} 12$ treatment groups, respectively. A "B" indicates that average confidence intervals are $0.61,0.69,0.89$, and 0.74 for the $\mathrm{H} 0, \mathrm{H} 3, \mathrm{H} 6$, and $\mathrm{H} 12$ treatment groups, respectively. $\mathrm{A}$ "C" indicates that average confidence intervals are 1.55, 1.46, 1.32, and 1.48 for the $\mathrm{H} 0, \mathrm{H} 3, \mathrm{H} 6$, and $\mathrm{H} 12$ treatment groups, respectively.

${ }^{2}$ Treatment groups are as follows: heifers in the H0, H3, H6, and $\mathrm{H} 12$ treatment groups were fed the lowenergy diet for $12,9,6$, or $0 \mathrm{wk}$, followed by the high-energy diet for 0,3 , 6 , or $12 \mathrm{wk}$, respectively. The low-energy diet and high-energy diet were formulated for gains of 0.6 and $1.2 \mathrm{~kg} / \mathrm{d}$, respectively.

${ }^{3}$ Pooled SE using treatment $\times$ purchase group or pen as the error term, with 4 pens per treatment. Data is based on 3 independent images per heifer.

${ }^{4} \mathrm{~L}=$ linear; $\mathrm{Q}=$ quadratic; $\mathrm{C}=$ cubic.

${ }^{5}$ Range 0 to 4 , where $0=$ least developed and $4=$ most developed.

${ }^{6} \mathrm{TDU}=$ terminal ductal unit; SUB = subtending duct.
} 
Table 5. Least squares means for daily compounded fractional accretion rates $(\mathrm{FAR})^{1}$

\begin{tabular}{|c|c|c|c|c|c|c|c|c|}
\hline \multirow[b]{2}{*}{ Item } & \multicolumn{4}{|c|}{ Treatment group ${ }^{2}$} & \multirow[b]{2}{*}{$\mathrm{SE}^{3}$} & \multicolumn{3}{|c|}{$P$-value for contrast ${ }^{4}$} \\
\hline & $\mathrm{H} 0$ & H3 & H6 & H12 & & $\mathrm{L}$ & Q & $\mathrm{C}$ \\
\hline Heifers, $\mathrm{n}$ & 16 & 15 & 16 & 15 & & & & \\
\hline Extraparenchymal fat FAR, \% & 1.14 & 1.52 & 1.98 & 2.35 & 0.09 & $<0.01$ & 0.08 & 0.42 \\
\hline Parenchymal FAR, \% & 2.53 & 2.60 & 2.68 & 2.65 & 0.08 & 0.31 & 0.44 & 0.80 \\
\hline Fat-free parenchymal FAR, \% & 2.37 & 2.42 & 2.44 & 2.37 & 0.09 & 0.92 & 0.48 & 0.94 \\
\hline Intraparenchymal fat FAR, \% & 3.89 & 4.05 & 4.33 & 4.46 & 0.10 & $<0.01$ & 0.29 & 0.44 \\
\hline RNA FAR, \% & 2.08 & 2.24 & 2.23 & 2.22 & 0.09 & 0.50 & 0.30 & 0.64 \\
\hline DNA FAR, \% & 2.80 & 2.88 & 2.96 & 2.93 & 0.09 & 0.32 & 0.43 & 0.86 \\
\hline BW FAR, \% & 0.49 & 0.49 & 0.58 & 0.71 & 0.01 & $<0.01$ & 0.01 & 0.02 \\
\hline Carcass weight FAR, \% & 0.40 & 0.48 & 0.60 & 0.78 & 0.009 & $<0.01$ & 0.36 & 0.12 \\
\hline
\end{tabular}

${ }^{1}$ Variable "x" FAR $=\exp \{[\ln (\mathrm{x}$ at end of study $)-\ln (\mathrm{x}$ for baseline $)] / 84\}-1$ (where $84 \mathrm{~d}=12 \mathrm{wk}=$ length of treatment period).

${ }^{2}$ Treatment groups are as follows: heifers in the H0, H3, H6, and H12 treatment groups were fed the lowenergy diet for $12,9,6$, or $0 \mathrm{wk}$ followed by the high-energy diet for $0,3,6$, or $12 \mathrm{wk}$, respectively. The lowenergy diet and high-energy diet were formulated for gains of 0.6 and $1.2 \mathrm{~kg} / \mathrm{d}$, respectively.

${ }^{3}$ Pooled SE using treatment $\times$ purchase group or pen as the error term, with 4 pens per treatment.

${ }^{4} \mathrm{~L}=$ linear; $\mathrm{Q}=$ quadratic; $\mathrm{C}=$ cubic.

bertal heifers indicated that a high-energy diet fed for durations as short as 3 or $6 \mathrm{wk}$ is not stimulatory to mammogenesis and instead inhibits mammary growth relative to body growth in a time-dependent manner, consistent with a 12 -wk duration. Perhaps the reported benefits of the stairstep regimen or of high-energy intake preweaning on mammary growth are not a result of feeding a high-energy diet for a short duration, per se, but instead are a result of feeding for rapid or slow growth at specific times in a heifer's growth curve.

The growth and development of the mammary gland in dairy heifers is crucial to productivity, because the number of mammary epithelial cells is a major factor determining milk production (Tucker, 1981). Before puberty, the mammary gland grows at a faster rate than the rest of the body, but around the onset of puberty, the rate of mammary growth slows and becomes isometric relative to other tissues (Sinha and Tucker, 1969). Although the impact of mammary parenchymal mass and DNA content at puberty on future milk yield has never been directly demonstrated, many studies support such a link, and prepubertal mammary development is considered to be an important factor affecting future milk production (Sejrsen, 1994). Thus, any management scheme that decreases the rate of mammary growth or hastens puberty would be expected to have long-term detrimental effects on milk yield.

The onset of puberty is influenced by BW, degree of body fatness, and plane of nutrition (Schillo et al., 1992). Heifers fed a high-energy diet during the prepubertal period reached puberty at a younger age than heifers fed a moderate- or low-energy diet (Schillo et al., 1992; Radcliff et al., 1997; Lammers et al., 1999). In this study, all heifers were slaughtered at $23 \mathrm{wk}$ of age, and all but one was prepubertal (one H12 heifer had a corpus luteum and was deleted from the data set). A longer duration of feeding the high-energy diet increased both BW and CW, but not mammary parenchymal mass. In fact, the H12 treatment, compared with H0, increased the FAR of BW and CW by 45 and 95\%, respectively, but did not alter the FAR of fat-free parenchyma. Thus, mammary data were adjusted for CW to more accurately reflect the difference in physiological maturity of the heifers. We chose $\mathrm{CW}$ instead of BW because of the difference in the forage:concentrate ratios in the diets, which altered the mass of digesta between the $\mathrm{H} 0$ treatment and the other 3 treatment groups at slaughter. Feeding the high-energy diet for a longer duration decreased the mass of fat-free mammary parenchymal tissue per unit of carcass in a linear, time-dependent manner. This finding is consistent with previous studies showing that heifers fed high-energy diets tended to have less parenchymal DNA when adjusted for BW (Petitclerc et al., 1984). We expect that if our heifers had been slaughtered at the onset of puberty, the amount of mammary parenchymal tissue would have been greater in the heifers fed the lowenergy diet than heifers fed the high-energy diet. Therefore, part of the mechanism by which feeding highenergy diets impairs mammary growth relative to body growth is that it hastens the onset of puberty and thus shortens the allometric phase of mammary growth.

It is not clear, however, why feeding a high-energy diet to heifers between 11 and 23 wk of age stimulated the accretion of muscle and fat but did not stimulate the accretion of mammary parenchymal tissue. Certainly not all body tissues respond to the metabolic and hormonal milieu in blood in the same manner. However, in younger heifers (2 to 8 wk of age), our laboratory previously found that mammary parenchymal tissue 
was more responsive to high-energy and high-protein intake than other body tissues (Brown et al., 2005a,b). In fact, higher energy and protein intake by preweaned calves increased BW gain by $76 \%$ but increased the mass of mammary parenchymal tissue by $275 \%$ so that, after adjusting for BW, mammary parenchymal mass was 3 times greater in calves fed for high-energy compared with moderate-energy and moderate-protein intake. A question remains regarding why high-energy intake has a positive effect on mammary growth in calves, but in older prepubertal heifers the outcome is either static or negative. However, one difference between these 2 studies was that the calves in the Brown study were at a point in the growth curve when there was little total body fat accretion and there was no treatment effect on the percentage of carcass fat. We speculate that dietary effects on body fatness may play a role in the differential age response of highenergy intake on mammary growth.

Results from this study indicate that the percentage of Ki-67-positive epithelial cells in the TDU decreased in a linear fashion with a longer duration on the highenergy diet. This suggests that heifers fed the low-energy diet had a greater rate of epithelial cell proliferation within the distal branching structures, which is where active ductal expansion is occurring. Meyer et al. (2006a) recently showed no effect of high-energy intake in prepubertal heifers on the rate of epithelial cell proliferation as measured by incorporation of bromodeoxyuridine; however, the high-energy diet in their study supported only $0.95 \mathrm{~kg}$ of BW gain per day. Perhaps the reason the rate of proliferation was decreased in our study but not theirs is that our high-energyfed heifers were growing faster. In our study, the H12 heifers gained an average of $1.09 \mathrm{~kg} / \mathrm{d}$ over the 12 -wk period and were gaining $1.19 \mathrm{~kg} / \mathrm{d}$ in the last week before slaughter. A reduction in the percentage of proliferating cells indicates that if heifers had been fed the high-energy diet for more than $12 \mathrm{wk}$, we might have observed a decrease in mammary parenchymal mass even without adjusting for body growth.

The mechanism for direct inhibition of high-energy intake on mammary growth is not clear. In this study, a longer duration of the high-energy diet increased the mass of extraparenchymal and intraparenchymal mammary fat. This was expected based on previous studies. For example, prepubertal heifers fed high-energy diets containing corn silage had more fat deposited within the mammary gland (Capuco et al., 1995). An increase in body fatness, which was also observed in these heifers (Davis Rincker et al., 2008), is negatively correlated with mammary parenchymal DNA and milk production (Silva et al., 2002b). Similarly, the amount of mammary secretory tissue is inversely related to extraparenchymal fat mass in heifers (Sejrsen et al., 1982). The growth of mammary epithelial cell organoids was inhibited when cocultured with bovine mammary fat pad explants (McFadden and Cockrell, 1993). In addition, mammary tissue extracts from prepubertal heifers fed a high-energy compared with a moderateenergy diet were less mitogenic for mammary epithelial cells in vitro (Weber et al., 2000; Berry et al., 2003). These studies demonstrate that heifers fed a high-energy diet have an increased deposition of fat and that mammary fat may secrete a factor that inhibits mammary epithelial cell growth. Our laboratory has suggested that leptin may be this inhibitory factor because of evidence from both in vitro and in vivo studies (Silva et al., 2002a, 2003), although Thorn et al. (2006) did not observe a similar effect in vitro.

\section{CONCLUSIONS}

We conclude that increasing the dietary energy intake of prepubertal heifers for a short duration does not improve mammary growth, but rather inhibits mammary growth relative to body growth in a timedependent manner, consistent with feeding a high-energy diet for a long duration. Feeding a high-energy diet for a longer duration decreased the mass of fatfree mammary parenchymal tissue adjusted for CW in a linear fashion. An increase in body or carcass growth without a proportional increase in mammary growth would result in less mammary parenchymal tissue at puberty because heifers fed for rapid gains typically reach puberty at a younger age. In addition, feeding a high-energy diet for a longer duration linearly decreased the percentage of Ki-67-labeled epithelial cells in the TDU, which is where active ductal expansion is occurring. We speculate that high-energy feeding both hastens puberty and decreases the proliferation of mammary epithelial cells in the distal branching structures of mammary parenchymal tissue. Both of these actions would be expected to decrease mammary parenchymal mass at puberty, and would be consistent with studies showing decreased subsequent milk production of prepubertal heifers fed for gains greater than 1,000 g/d.

\section{REFERENCES}

AOAC. 1990. Official Methods of Analysis. 15th ed. Assoc. Off. Anal. Chem., Arlington, VA.

Bar-Peled, U., B. Robinzon, E. Maltz, H. Tagari, Y. Folman, I. Bruckental, H. Voet, H. Gacitua, and A. R. Lehrer. 1997. Increased weight gain and effects on production parameters of Holstein heifer calves that were allowed to suckle from birth to six weeks of age. J. Dairy Sci. 80:2523-2528.

Berry, S. D. K., M. S. Weber Nielsen, K. Sejrsen, R. E. Pearson, P. L. Boyle, and R. M. Akers. 2003. Use of an immortalized bovine 
mammary epithelial cell line (MAC-T) to measure the mitogenic activity of extracts from heifer mammary extracts from heifer mammary tissue: Effects of nutrition and ovariectomy. Domest. Anim. Endocrinol. 25:245-253.

Brown, E. G., M. J. VandeHaar, K. M. Daniels, J. S. Liesman, L. T. Chapin, J. W. Forrest, R. M. Akers, R. E. Pearson, and M. S. Weber Nielsen. 2005a. Effect of increasing energy and protein intake on mammary development in heifer calves. J. Dairy Sci. 88:595-603.

Brown, E. G., M. J. VandeHaar, K. M. Daniels, J. S. Liesman, L. T. Chapin, D. H. Keisler, and M. S. Weber Nielsen. 2005b. Effect of increasing energy and protein intake on body growth and carcass composition of heifer calves. J. Dairy Sci. 88:585-594.

Capuco, A. V., J. J. Smith, D. R. Waldo, and C. E. Rexroad Jr. 1995 Influence of prepubertal dietary regimen on mammary growth of Holstein heifers. J. Dairy Sci. 78:2709-2725.

Choi, Y. J., I. K. Han, J. H. Woo, H. J. Lee, K. Jang, K. H. Myung, and Y. S. Kim. 1997. Compensatory growth in dairy heifers: The effect of a compensatory growth pattern on growth rate and lactation performance. J. Dairy Sci. 80:519-524.

Davis Rincker, L. E., M. S. Weber Nielsen, L. T. Chapin, J. S. Liesman, and M. J. VandeHaar. 2008. Effects of feeding prepubertal heifers a high-energy diet for three, six, or twelve weeks on feed intake, body growth, and fat deposition. J. Dairy Sci. 91:1913-1925.

Hach, C. C., B. K. Bowden, A. B. Kopelove, and S. V. Brayton. 1987. More powerful Kjeldahl digestion method. J. AOAC 70:783-787.

Heinrichs, A. J. 1993. Raising dairy replacements to meet the needs of the 21st century. J. Dairy Sci. 76:3179-3187.

Lammers, B. P., A. J. Heinrichs, and R. S. Kensinger. 1999. The effects of accelerated growth rates and estrogen implants in prepubertal Holstein heifers on estimates of mammary development and subsequent reproduction and milk production. J. Dairy Sci. 82:1753-1764

McFadden, T. B., and D. C. Cockrell. 1993. Regulation of growth in cultured mammary epithelium from beef and dairy heifers. Proc. N. Z. Soc. Anim. Prod. 53:143-145.

Meyer, M. J., A. V. Capuco, D. A. Ross, L. M. Lintault, and M. E. Van Amburgh. 2006a. Developmental and nutritional regulation of the prepubertal bovine mammary gland: II. Epithelial cell proliferation, parenchymal accretion rate, and allometric growth. J. Dairy Sci. 89:4298-4304.

Meyer, M. J., A. V. Capuco, D. A. Ross, L. M. Lintault, and M. E. Van Amburgh. 2006b. Developmental and nutritional regulation of the prepubertal heifer mammary gland: I. Parenchyma and fat pad mass and composition. J. Dairy Sci. 89:4289-4297.

Park, C. S., R. B. Danielson, B. S. Kreft, S. H. Kim, Y. S. Moon, and W. L. Keller. 1998. Nutritionally directed compensatory growth and effects on lactation potential of developing heifers. J. Dairy Sci. 81:243-249.

Petitclerc, D., L. T. Chapin, and H. A. Tucker. 1984. Carcass composition and mammary development responses to photoperiod and plane of nutrition in Holstein heifers. J. Anim. Sci. 58:913-919.

Petitclerc, D., P. Dumoulin, H. Ringuet, J. Matte, and C. Girard. 1999. Plane of nutrition and folic acid supplementation between birth and four months of age on mammary development of dairy heifers. Can. J. Anim. Sci. 79:227-234.

Radcliff, R. P., M. J. VandeHaar, L. T. Chapin, T. E. Pilbeam, D. K. Beede, E. P. Stanisiewski, and H. A. Tucker. 2000. Effects of diet and injection of bovine somatotropin on prepubertal growth and first-lactation milk yields of Holstein cows. J. Dairy Sci. 83:23-29.

Radcliff, R. P., M. J. VandeHaar, A. L. Skidmore, L. T. Chapin, B. R. Radke, J. W. Lloyd, E. P. Stanisiewski, and H. A. Tucker. 1997. Effects of diet and bovine somatotropin on heifer growth and mammary development. J. Dairy Sci. 80:1996-2003.

SAS Institute. 1999. SAS/STAT User's Guide. Release 8.1 Edition. SAS Inst., Inc., Cary, NC.

Schillo, K. K., J. B. Hall, and S. M. Hileman. 1992. Effects of nutrition and season on the onset of puberty in the beef heifer. J. Anim. Sci. 70:3994-4005.

Sejrsen, K. 1994. Relationships between nutrition, puberty and mammary development in cattle. Proc. Nutr. Soc. 53:103-111.

Sejrsen, K., J. T. Huber, H. A. Tucker, and R. M. Akers. 1982. Influence of nutrition of mammary development in pre- and postpubertal heifers. J. Dairy Sci. 65:793-800.

Sejrsen, K., and S. Purup. 1997. Influence of prepubertal feeding level on milk yield potential of dairy heifers: A review. J. Anim. Sci. 75:828-835.

Shamay, A., D. Werner, U. Moallem, H. Barash, and I. Bruckental. 2005. Effect of nursing management and skeletal size at weaning on puberty, skeletal growth rate, and milk production during first lactation of dairy heifers. J. Dairy Sci. 88:1460-1469.

Silva, L. F. P., J. S. Liesman, M. S. Weber Nielsen, and M. J. VandeHaar. 2003. Intramammary infusion of leptin decreases proliferation of mammary epithelial cells in prepubertal heifers. J. Dairy Sci. 86(Suppl. 1):685. (Abstr.)

Silva, L. F. P., M. J. VandeHaar, M. S. Weber Nielsen, and G. W. Smith. 2002a. Evidence for a local effect of leptin in bovine mammary gland. J. Dairy Sci. 85:3277-3286.

Silva, L. F. P., M. J. VandeHaar, B. K. Whitlock, R. P. Radcliff, and H. A. Tucker. 2002b. Short communication: Relationship between body growth and mammary development in dairy heifers. J. Dairy Sci. 85:2600-2602.

Sinha, Y., and H. A. Tucker. 1969. Mammary development and pituitary prolactin levels of heifers from birth through puberty and during the estrous cycle. J. Dairy Sci. 52:507-512.

Thorn, S. B., S. Purup, W. S. Cohick, M. Vestergaard, K. Sejrsen, and Y. R. Boisclair. 2006. Leptin does not act directly on mammary epithelial cells in prepubertal dairy heifers. J. Dairy Sci. 89:1467-1477.

Tucker, H. A. 1964. Influence of number of suckling young on nucleic acid content of lactating rat mammary gland. Proc. Soc. Exp. Biol. Med. 116:218-220.

Tucker, H. A. 1981. Physiological control of mammary growth, lactogenesis, and lactation. J. Dairy Sci. 64:1403-1421.

Weber, M. S., S. Purup, M. Vestergaard, R. M. Akers, and K. Sejrsen. 2000. Nutritional and somatotropin regulation of the mitogenic response of mammary cells to mammary tissue extracts. Domest. Anim. Endocrinol. 18:159-164. 